Visit us - www.researchjournal.co.in $\mathbf{D}$ DOI : 10.15740/HAS/IRJAES/6.2/282-286

International Research Journal of Agricultural Economics and Statistics

Volume 6 | Issue 2 | September, 2015 | 282-286 a ISSN-2231-6434

\title{
Research Paper A study of seasonal price behaviour and market concentration of maize in Rajasthan
}

\section{- HEMANT SHARMA AND S.S. BURARK}

See end of the paper for authors' affiliations

Correspondence to : HEMANT SHARMA Agro-Economic Research Centre, Sardar Patel Univesity, Vallabh Vidyanagar, ANAND (GUJARAT) INDIA

Email: sharmah007@ gmail.com

\section{Paper History :}

Received : 26.02.2015;

Revised : 18.06.2015,

Accepted : 17.07.2015
AbSTRACT : The paper investigates the price behaviour of maize and market concentration in Nimbahera market of Rajasthan. In view of this the present study was undertaken by collecting monthly wholesale prices of maize in major maize markets of Rajasthan for a period of 12 years (2002 to 2013).The seasonal price index pro ides a measure of the month to month variation in maize prices. Price of maize was found to be highest during off season and lowest during harvest season. Since maize is a Kharif crop, the arrivals were high during October to January. The higher seasonal indices of prices were observed during April to August during which the arrivals were found to be low. The Lorenz ratio was less than 0.5 in Nimbahera market. it can be concluded that the moderate market competitiveness in markets as the arrivals were concentrated among few large traders. The Lorenz ratio 0.49 for maize in Nimbaheda market showing moderate market concentration.

KEY WordS : Price, Seasonal, Maize, Market, Arrivals

How To Cite This PAper : Sharma, Hemant and Burark, S.S. (2015). A study of seasonal price behaviour and market concentration of maize in Rajasthan. Internat. Res. J. Agric. Eco. \& Stat., 6 (2) : 282-286. 